Studia Anglica Posnaniensia 49/3, 2014

doi: 10.1515/stap-2015-0006

\title{
THE RISE OF STANDARD I $(<$ ME ICH): A CONTRIBUTION TO THE STUDY OF FUNCTIONAL CHANGE IN ENGLISH
}

\author{
JERZY WELNA
}

University of Warsaw

\begin{abstract}
In its post-Norman Conquest development the Old English first person personal pronoun ic underwent transformations which, following the loss of the consonant, finally yielded the contemporary capitalised form $I$, contrasting with other Germanic languages, which retain a velar sound in the corresponding pronoun. The rather complex change of ich to $I$ involves a loss of the final velar/palatal consonant, lengthening of the original short vowel, and capitalisation of the pronoun. It is argued here that the use of the capital letter was a consequence of vowel lengthening subsequent to the loss of the consonant. This seems to be confirmed by the observation that forms retaining a consonant are extremely rarely capitalised. The data adduced in the present paper will help verify as precisely as possible the distribution of the forms of that pronoun in Middle English dialects in order to determine to what extent the changes were functionally interdependent. The evidence comes from the Innsbruck Corpus of Middle English Prose.
\end{abstract}

Keywords: Pronoun, first person, I, ich, Old English, Middle English, functional change

\section{Preliminaries}

The Old English first person personal pronoun ic 'I' with the short high vowel [i] "must have been the unstressed form, with analogical introduction of its vowel into the stressed form”, write Hogg \& Fulk (2011: 203). As regards the final consonant in the pronoun, English is the only language in the Germanic family in which that velar (or palatalised) consonant of the first person personal pronoun was dropped. While other Germanic languages consistently retain the velar sound (cf. PGmc *ek, $i k$ and OFris., OS, Goth., Du. ik, OHG. ih: MHG/G. ich, ON ek, eg: Norw. eg, Sw. jag, Da. jeg), it is the form without a consonant which survives in English. The rather complex evolution of ich to $I$ is marked by three "irregular" events: 
(a) loss of the final velar/palatal consonant;

(b) lengthening of the original short vowel;

(c) capitalization of the word.

The purpose of the paper is to verify as precisely as possible the regional and temporal distribution of the forms of that pronoun in dialects throughout the Middle English period in order to examine to what extent they may have been functionally interdependent. The evidence comes from the Innsbruck Corpus of Middle English Prose (Marcus 2008).

\title{
2. Origins
}

In their study of Indo-European languages, Mallory \& Adams (2006: 416) point to the various potential sources of the nominative form of the first person personal pronoun, stating that it "might be derived from the PIE first person or from the emphatic form or from the accusative". The Germanic languages, together with Italic, Baltic and Armenian derive the pronoun from the nominative form $* h_{1} e \hat{g}$. A slightly different proto-form, $* e ́ g h_{2}$, suggested by Ringe (2006: 99) develops into PGmc *ek (unstressed *ik), and finally yields the Old English standard form ic, where the grapheme $<\mathrm{c}>$ represents palatalised [ $\mathrm{g}$ ]

The subsequent fates of the continuations of $\mathrm{OE}$ ic are described by the compilers of the Oxford English Dictionary (OED) as follows:

\begin{abstract}
OE. ic remained in ME. as ic, ik in the north; in midl. and south it was early palatalized to ich ( $\mathrm{It})$. In north and midl. the final consonant began by 12th c. to be dropped before a consonant, the pronoun being in this position reduced to $\mathrm{i}$; in the 14th c. ik and i were still used before vowel and consonant respectively in the north, but I alone appears in north and midl. after c. 1400. In the south, ich remained much longer, esp. before an initial vowel, in which position, also, it was in 16th c. commonly reduced to ch ...The ME. ic, ik, ich, were also spelt yk, ych (e; i varied with $\mathrm{j}$ or I (the MS. character for these being often the same), also with $\mathrm{y}, \mathrm{Y}$, and finally at the introduction of printing settled down as I. (OED, s.v. I)
\end{abstract}

A somewhat different account of the change is found in Brunner. In his grammar of Middle English the Austrian linguist (1963: 58) states the following:

Nom.: ich; later I (from the 12th century, first before words with an initial consonant, particularly [ $\check{\text { s }}]$ as in ischall for ich schall; in the North $I$ is from OE ih with $h$ for $c$ finally in an unstressed word); in the North also $i k$ (based on ON ek).

As regards the capitalized spelling $<\mathrm{I}>$, Brunner (1962: 100) offers the following curious explanation: 
Die Schreibung von I mit dem Grossbuchstaben stammt aus der Zeit der ersten Drucker bzw. aus der Schrift der ausgehenden me. Zeit. Der Deutlichkeit halber wurde me. das Pronomen statt mit $i$ oft mit $j$ geschrieben und $j$ war in der Schrift des späteren 15. Jhs. einem $I$ oft gleich. Dieses wurde dann von der Druckern übernommen und hat sich erhalten.

The last remark must be a repetition of what Mossé (1952: 12) suggested in his Handbook, which contains an account of the following complex chain of events:

... ich is the stressed form of the South and the Midlands (also written $i \dot{c}$ up to $1200) ; i c, i k$ is the stressed form of the North. The latter form very early gave rise to an unstressed form $y, I \ldots$ which was used first, north of the Thames, before a word beginning with a consonant ...; little by little this unstressed form became the general usage in the common language of the 14th century and even invaded the area south of the Thames, where, however, ich remained the usual form... Note that in Middle English $I$ is always short [I]. It is only in the 15th century that the vowel was lengthened in a stressed position ... (Mossé 1952: 55)

The authors of textbook grammars believe that the first forms of non-capitalised $i$ appeared in the North and Midlands in the 13th century, at first as unstressed variants contrasting with the stressed form ich, which survived in the South. The contemporary form with capitalized $I$ is said to be "a restressed variant of the originally unstressed ME $i$." (Horobin \& Smith 2002: 112; also Fisiak 1968: 80). As regards the Northern dialect, the scribes who composed the four most important manuscripts of Cursor Mundi (Northern: Cotton, Fairfax, Göttingen, West Midland: Trinity) employed the forms $I, i, I c, i c, j$.

Basing on the OED data, the temporal conditioning of the evolution of the 1st person pronoun may have been as follows:

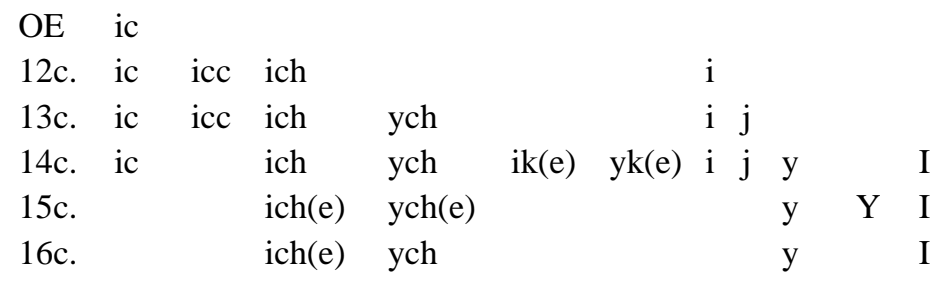

[also: ig, ih(c), hic(h), hyc, hi, $e$ in different periods]

The peripheral forms such as ig, ih(c), hic(h), hyc, hi, e occasionally used in dialects in different centuries are not represented under (1) because of their relatively low frequency and lack of influence on the then system of personal pronouns becoming established in English. On the basis of data from the prose texts collected in the Innsbruck Corpus in what follows we shall verify whether 
materials in that collection support such a distribution of the forms of the first person singular personal pronoun in Middle English.

The texts collected in the Innsbruck Corpus are in majority of cases more or less precisely localised. Because the regional aspect is essential in the present study, the unclassified texts were eliminated from the analysis. Considering the limited scope of the present research, other Middle English corpora were not examined.

In sum, the present study contains an analysis of 103 texts representing the principal English dialects: East Midland (31), London (24), Northern and Irish (15), West Midland (14), Southern) (8) and Kentish (3). Several dialectally impure texts (8) representing the East or West Midland region and labelled by the Innsbruck Corpus editors as having mixed origin were also considered in the examination. The total number of words in the texts under examination (103 texts) amounts to ca. 4 million items.

It seems that special attention should be given to the instances where different variants of the lemma $I$ (ich/I/y etc.) stand in the close vicinity of one another because such co-occurrence testifies to the progress of the competition between the conservative and advanced forms.

\section{Old English and Early Middle English (12th century)}

Practically, Old English lacked variants of the principal form ic, although two texts from Northumbria, Rushworth ${ }^{2}$ and the Lindisfarne Gospels, supply the occasional alternative form ih (also ich in the Gospels; cf. Brunner 1965: 259). The scarcity of texts from the centuries directly following the Norman Conquest is also seen in the Innsbruck Corpus, which suffers lack of dialectal texts from the early period. Perhaps their list could have been longer had it not been for the temporal gap between the date of the surviving manuscripts and the date when the text was originally composed. Such time distance sometimes represents periods of more than 100 years so that texts with gaps of, say, around 20 years between the original, non-existent version, and the surviving manuscripts are sometimes viewed as well-matched in time. Holographs like Ormulum can hardly be found among prose texts from the Innsbruck Corpus, with the notable exception of epistolary literature.

As regards the 12th century Middle English prose pieces, the Innsbruck Corpus especially lacks texts from the North. It only contains one localised text from the East Midland and one from the West Midland with the following distribution of forms: 
(2)

The Peterborough Chronicle 1070-1154

ic ich i I

(Oxford, Bodley Laud Misc. 636) 1100+ (EM)

Liflade and Passion of St. Julian

42

(Oxford, Bodley,Royal 34) 1150+ (WM)

601

Examples:

PChr. Laferd kyng, ic swelte.(42/9), I ne can ne I ne mai tellen alle pe wunder $(56 / 34)$

Liflade. ich ne dar ich cumen biuoren him (46/390), i... ne ga i neauer eft mare... (65/551-552)

Comparing this with the $O E D$ data, according to which capitalized $I$ appears as late as the 14th century, one finds that the Peterborough Chronicle (East Midland) contains 2 tokens corresponding to the contemporary form of capitalized I, while ich (60 tokens) predominates in Liflade and Passion (West Midland), with a single occurrence of non-capitalised $i$. However, the number of contrastive, conservative and advanced forms in particular 12th century texts, all composed after 1150, is even less than scant. As regards non contrastive forms, the exclusive form ich is used by the scribes who copied the West Midland texts Hali Meidhad, Sawles Warde, further Old English Homilies, Seinte Marherete (both Bodley 34), and the Southern texts: History of the Holy Rood-tree (Oxford, Bodley 343), Hali Meidenhad (Bodley 34, 52v ff), Hali Meidenhad (BL Cotton Titus D 18f. 112v ff.), Twelfth-Cent. Homilies (Bodley 343). The only text from Kent, Twelfth-Cent. Homilies (Oxford, Vespasian D. XIV), retains the conservative form ic exclusively.

\section{Early Middle English (13th century)}

The 13th century evidence testifies to an intensive rivalry of the forms of the 1st person singular personal pronoun. It is a period in which both types, the one with the final velar, and the other with the velar deleted, began to appear side by side in the same text. Regrettably, the Innsbruck Corpus fails to supply any prose pieces of Northern origin representing the 13th century, but the number of texts containing contrastive forms of the personal pronoun grows, as shown below: 
(3)

Vices and Virtues (BM Stowe 240) 1200+ EM

Ancrene Riwle (Magd. Coll. Cbr. Pepys 2498) 1200+ EM

Ancrene Riwle (Cotton Titus D; Bodleian) 1200+ EM

Ancrene Riwle (B.L. Cotton Nero A. XIV) 1200+ WM?

Ancrene Riwle (Gonville \& Caius Coll. Cbr. 234) 1200+ WM?

Wohunge of Ure Lauerd (BL Cotton Titus B. 18) a1300 WM?

OE Homilies (Trinity Coll. Cbr., MS. B. 14.52) a1225 SW

$\begin{array}{llll}\text { ic } & \text { ich } & \text { i } & \text { I } \\ 183 & 51 & 4 & \\ & 148 & 121 & 62 \\ & 115 & 73 & \\ 3 & 333 & & \\ & 150 & 1 & \\ & 8 & 27 & \\ & & & \\ 3 & 103 & & \end{array}$

Examples:

$V \& V$ Ic wende habben strengbe of me seluen, and for ði i fell (84/r23-24)

$A R$ Pep. ... pat I ne may nouhth and pat me sore reweb. And longe it is agon pat ich it wist first Ac euere ich haue stilled it vn to now. Ac for me schulde it nouhth haue comen forper. Ac now it is so ferforp brouhth pat i ne may it nouhth wipsaken (35/r11-15).

$A R$ Tit ... I wile leade pe he seis to his lefmon into anli stude \& ich wule speke luueliche to pin herte. for me is lað presse (51/21-22).

$A R$ Nero ... ic chulle witen mine weies (34/r8), pat ich chulle speken of puruh ower bone $(1 / \mathrm{r} 11)$

$A R$ G/Cai. Ich habbe peos twa leddre steolen (32/r12); i ne mai pe forgeten neauer $(44 / \mathrm{r} 30)$

Wohunge ... for $\mathbf{i}$ be ane mai ich alle frend finden (p. 276)

OEH Ic bileue on god (p. 18), Ich bileue on pe helende crist (p. 22)

Regrettably, Kentish Sermons, in Old English Miscellany (Oxford Laud MS. $471,1250+$ ) contains no token of the first person singular pronoun. Two other texts from the period, Life of St. Katherine (BL Royal. 17 A XXVII) and Seinte Marherete (BL Royal 17 A. XXVII), both from the West Midlands (Herefordshire), demonstrate conservative language as they contain only forms of ich (72 and 97 respectively). On the opposite side is the West Midland version of Ancrene Riwle (Corpus Christi Coll. Cbr. 402) which contains 9 occurrences of capitalized I (cf. ... while I will, and when I will; 3/19). This capitalized spelling is not listed as a 13th century form in the $O E D$. It is to be noted that around 20 occurrences of capitalized I in Ancrene Riwle (MS Titus) only stand in sentence initial position so they had to be classified together with non-capitalised $i$.

The statistics under (3) shows that the scribe who copied Vices and Virtues proved to be very conservative, giving preference to the quasi-Old English spelling <ic> (183 tokens). In the 13th century prose, the most popular form was less conservative ich with $<\mathrm{h}>$, appearing in all localised texts in high numbers, except in Wohunge, probably composed at the end of the period. In general, the prose texts of the period in the Innsbruck Corpus which represent the Midland 
region contain the traditional forms of the pronoun with the final consonant, the only exception being Ancrene Riwle (Pepys) which, apart from 148 tokens of conservative ich, also contains 121 occurrences of non-capitalised $i$ and 62 of capitalized I. Surprisingly many instances of the Old English form ic survive without modifying their spelling. The examination of texts in the Corpus failed to reveal forms like icc, $y c h$ and $j$ referred to in the $O E D$ (see item 1 above).

\section{Middle English (14th century)}

The 14th century may be regarded as the period of stabilisation in the evolution of English. That century witnessed intensive literary activity of London writers, enough to mention Chaucer and Gower, whose language shows a high degree of regularity. But as the manuscripts containing their literary works come from the 15th century, they are referred to in section 6 below devoted to the Innsbruck Corpus texts from that period.

The literary output of the Midland writers in the 14th century was high, especially as regards poetic works, but only a few manuscripts from the Innsbruck Corpus meet the requirements of the present study which is strictly based on the chronology of manuscripts, not on the dates of the text origin. As in the previous epochs, materials from the Northern dialect are in demand. Like on the preceding pages attention is focussed here on pieces of prose showing the competition of the forms of the personal pronoun; cf.:

(4)

Dan Michel's Ayenbite of Inwyt, or Remorse of Conscience (BL Autograph Ms. Arundel 57) 1300+ Kent

The Complaint of Our Lady and Gospel of Nicodemus (Cbrg Magd. Coll. Pepys 2498) 1350+, London

Lollard Sermons (BL Add. 41321; Bodl. Rawlinson C 751); a1400 South Central ML

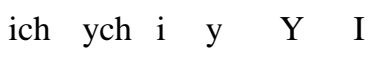

64

1

Examples:

Ayenb. Alsuo ich zigge of pe opre sacremens (p. 40); Vayre uader ych yelde pe ponkes and heriynges (p. 139); ham hep pet y do zigge. (p. 52)

Compl. And I leide myne honde opon pat tree and whan ich it hadde opon my schulder \& feled pe heuynesse (98/11-16); "He pat y kisse is Ihesus. (81/r7) 
Lollard ... I purpose at pis tyme to speke of pis comynge. (3/77); pis asse is bounden, as Y saide, wip long continuaunce (6/202)

The 14th century material is rather disappointing, although the incidence of the conservative forms shows that the chronologically earlier text localised in the southerly areas (Ayenbite) retains the final consonant, while Lollard Sermons exhibits the modern form without exceptions. One could supplement the above with the data from Mandeville's Travels (Oxford Bodl., E Musaeo 116; 1350+ EM) which also contains capitalized $I$ exclusively (83 occurrences) and from Trevisa's West Southern Methodius, The Bygynnyng of the World (BM Harley 1900; 1350+, with a single occurrence of y (It forpinkip me pat y made man; 96/r18)

\section{Late Middle English 1 (1401-1450)}

Because the majority of manuscripts exploited by the editors of the The Innsbruck Corpus come from the 15th century, a period often labelled as Late Middle English, their description in the present study corresponds to two chronological layers: from 1401 to 1450 and from 1451 to 1500 and beyond. The most important innovations in English spelling, pronunciation and grammar took place in the second half-century, while the time boundaries 1401-1450 embrace the texts originally representing the 14th century language of such prominent writers as Chaucer or Wycliff. In consequence the trend towards using capitalized forms of the personal pronoun without the final consonant is evident. Last but not least, linguistic evidence for the period from the North becomes available, so one can obtain a more comprehensive picture of how the form evolved in dialects. The following texts show variation in the employment of the personal pronoun under scrutiny:

(5)

Three ME Sermons (Chapter Libr. Worcester F. 10) 1400+, N Richard Rolle of Hampole ... and his Followers, vol. II, pt. 1, Yorksh. Writers (Cambr. UL Dd V. 64;

Rawl. C 285; Arundel 507) a1450 N

As above (Cambr. Dd V. 64) N

As above, Yorkshire Writers N

The English Conquest of Ireland A.D. 1166-1185

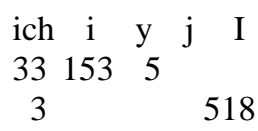


De Pater Noster of Richard Ermyte (Westminster School Libr.)

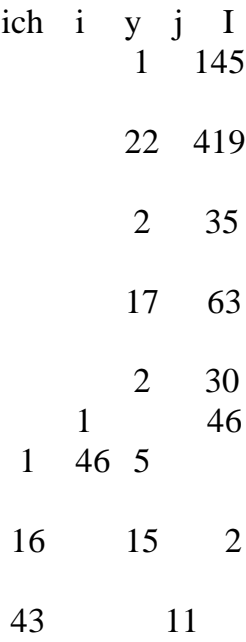

Julian of Norwich's Revelations (BL Add. 37790) 1400+ EM (Norf.)

Book of the foundation of St. Bartholomew's Church (BL Cotton Vesp. B ix), 1400+ London

English Works of Wyclif 1 (Oxford, Bodley 788 etc.) a1424 London?

As above 2: a 1425. London

The Equatorie of the Planetis (Peterhouse MS 75.I)

Three Middle English Sermons from the Worcester Chapter 10 (Chapter Library Worcester F. 10) 1400+ WM (1st serm.)

Trevisa Dialogus inter militem et clericum (BM Harley 1900, $1400+$ South (West Southern)

Pepysian Gospel Harmony (Magd. Coll., Cbr. MS Pepys 2498) $1400+\mathrm{EM} / \mathrm{S}$

Examples:

Three Sermons. ... ich am punschid e be same membir' bat i trespasid with (40/593)

$R R$... so graunte me bat $\mathbf{y}$ haue noon hunger (p. 377)

Engl. Conq. I wyll that hyt to the turne (41/r29), ... y went ynto Irland $(41 / \mathrm{r} 27)$

Pater Noster ...so wel y wot pei weren (18/r33), as I ere seyde (19/r26)

Julian ...I desyrede a body_lye syght whareyn $\mathbf{y}$ myght have more knawynge of bodelye paynes of oure lorde (39/r21-22)

Book of Foundation ...the howse of this forcryer or bedyl or, $\mathbf{y}$ may say, of that robber $(37 / 14-15)$

Wyclif ... \& now y commende hou to god and to word of his grace, whiche is myhty to edifye \& hiue heritage in alle (p. 300)

Dialogus ... I knowe hit well hit likep hou nouht to here pese wordes, \& nopeles y speke nouht but wordes of Holy Writ. (22/r12)

Pepysian Gospel ... and ich ne habbe nouhth where onne pat $\mathbf{j}$ may reste myne hede.(21/r1-2)

In the manuscripts from the first half of the 15th century a trend towards a complete elimination of the conservative forms with a consonant is evident, although a substantial number of forms retaining the consonant still survive in, e.g., southerly Pepysian Gospel Harmony (43) and in Northern Three Middle English Sermons (co-occurring with 153 forms of non-capitalized $i$ ), but, surprisingly, not in the West Midland fragments of Sermons. In sum, capitalized I is the dominant form, especially when we consider 22 texts from the period which employ larger numbers of that form exclusively, e.g., 
(6) Northern: Alphabet of Tales 1 (450), The Mirror of St.Edmund (45), Fistula in ano (240), Wisdom of Salomon (39)

East Midland: Life of Adam and Eve (106), Lantern of Light (83), Misyn's The Mending of Life (46) and The Fire of Love (473), Metham's Physiognomy (29), Nicholas Love's Mirror of the Blessed Life of Jesus Christ (389), Capgrave's Lives of St. Augustine (211), Deonise Hid Diuinite (111)

London: Speculum Sacerdotale (282), Chaucer's A Treatise on the Astrolabe (120), The Tale of Melibeus (two versions 122/109), The Persones Tale (two versions 78/79), De Consolatione Philosophie (392)

South: A Myrour to Lewde Men and Wymmen (58)

Perhaps the most characteristic event in the 15th century is the growing popularity of the spelling $\langle\mathrm{y}\rangle$ which undoubtedly replaced non-capitalised $\langle\mathrm{i}\rangle$ as it practically does not co-occur with the latter. Traces of competition between the two forms are only seen in the two versions of Three Middle English Sermons, where lowercase $y$ is vastly outnumbered by forms with lowercase $i$. Relatively many (16) forms of conservative ich survive in Trevisa's Dialogus.

\section{Late Middle English 2 (1451-1500)}

It is generally accepted that 1501 and the following years deserve to be called Early New English since that period witnessed stabilisation of English grammar. In fact all important changes in the language paved way to the establishment of linguistic standards on almost all levels of English. One of the crucial events was Caxton's introduction of the printing press in Westminster in 1476, which contributed to increased uniformity of orthography and standardisation of grammatical forms.

As regards the personal pronoun under discussion its distribution in the late 15th century prose presented the following pattern:

The Paston Letters, vol. 2 (1420-1500) EM

$P L$ vol. 3

$P L$ vol. 4

$P L$ vol. 5

$P L$ vol. 6

Lavynham, A Litil Tretys (BL Ms. Harley 211) 1450+, EM (Ipsw?)

Pecock, The Donet (Bodley 916) c1475, EM

Pecock, Follower to the Donet (BL Royal 17 D.ix) 1450+ EM

Dicts and Saying of the Philosophers (Bodley 943) 1450+ L

\begin{tabular}{lllll} 
y & Y & j & J & \multicolumn{1}{c}{ I } \\
49 & 2 & & 1189 \\
55 & & & 1274 \\
15 & & & 1555 \\
9 & & & 2654 \\
14 & & & 800 \\
6 & & & 1 \\
129 & & & 218 \\
685 & & & 13 \\
58 & & & 207
\end{tabular}


The Revelations of Saint Birgitta (Princeton Univ.) 1450+ L The Knight of La Tour-Landry (BL, Harley 1764) 1450+ L Caxt. Blanchardyn and Eglantine (Lord Spencer) M 1450+ L? The Tretyse of Loue (Pierpont Morgan Libr.) M 1450+ L

Three Lives from the Gilte Legende (ME Religious Prose) M? L Prologues and Epilogues of Caxton, 1 ed. (different prints) L Prologues and Epilogues of Caxton, 2 ed. (different prints) L LME Treatise on Horses (BL Sloane 2584, 1500+ S/WM/EM) Saint Bartholomew (BL Egerton 876) 1450+, WMO? / London?

\begin{tabular}{|c|c|c|c|}
\hline $\begin{array}{ll}\mathrm{y} & \mathrm{Y} \\
7 & \end{array}$ & $\mathrm{j}$ & $\mathrm{J}$ & $\begin{array}{c}\text { I } \\
692\end{array}$ \\
\hline \multirow[t]{3}{*}{346} & & & 205 \\
\hline & 2 & & 334 \\
\hline & 32 & & 270 \\
\hline 2 & & & 28 \\
\hline \multirow[t]{2}{*}{6} & & 62 & 252 \\
\hline & & 6 & 90 \\
\hline 0 & 3 & & 9 \\
\hline 4 & & & \\
\hline
\end{tabular}

\section{Examples:}

The Paston Letters, vol. 2, ... and this werk shal be strong $\mathbf{j}$ nowe, as werkmen seyn, and drawe but litill cariage. I wold have swiche stoan a xxti. tunne tight caried to Moneslee in Norffolk... (p. 19)

The Donet I entende not to commende my silf, as for my silf, in eny wordis which y schal write or seie (82/r21-22)

Dicts and Saying of the Philosophers ... bi the whiche $\mathbf{y}$ may put in effecte alle pat I wille vndertake; and $\mathbf{y}$ send the a rounde (186/r2)

The Revelations ... for $\mathbf{y}$ was and am all way. I am also pat lorde whos power none may wythstonde (13/r32)

Blanchardyn and Eglantine ... I merueyll me not for on my feyth ye be well the man that ought to chuse your specyall loue in a hyghe place. But[ ...] it is force that $\mathbf{j}$ bere you in hande (75/8-11)

The Tretyse of Loue ... whanne I stode he sustyened me; whanne j hode he led me $(7 / \mathrm{r} 22)$

Prologues and Epilogues of William Caxton, 2nd ed... J beseche you not tarette the faulte in me but in hym that made my copye. whiche book I began first to tra[n]slate.. (p. 59)

Treatise on Horses I wol schewe hou as $\mathbf{j}$ haue jlerned sum curus for hors $(85 / 8)$

The late 15th century prose texts demonstrate an almost general acceptance of the standard capitalized form $I$ of the 1st person singular personal pronoun. The conservative forms with the final consonant still present in the first half of the 15th century are not found any more in late 15th century texts from the Innsbruck Corpus. What is even more peculiar lowercase $i$ forms are also missing replaced by forms with lowercase $j$ and capital $J$. Consequently as many as three forms of the pronoun are capitalized letters: the standard form $I$ and the occasional forms $Y$ and $J$.

The prevalence of capitalized $I$ is also documented by a number of texts in which it is the only form first person pronoun. Those containing more substantial numbers (in parentheses) are listed under (8): 
Northern: Alphabet of Tales (later version; 519), Wisdom of Solomon (39)

East Midland: Metham's Physiognomy (29), Capgraves's Abbreviation of Chronicles (51), Macer Floribus (41), Speculum Christiani (121), Lincoln Diocese (372), Oseney Abbey (264)

London: Reynard the Fox (990), Malory's Le Morte Darthur (2052), Four Sons of Aymon (1316), The myracles of Oure Lady (79),

West Midland: Saint George (20)

The above numbers only confirm the statistical domination of capitalized $I$, which became a standard form in 15th century English.

\section{Conclusions}

The reasons for the rise of capitalized form $I$, now pronounced as a diphthong, seems to have been the effect of the interplay of various factors: phonological, orthographic, functional and sociolinguistic.

1. Phonology. The form ich was very frequently attached to the following verb with an initial vowel, for instance ich + am combined to create a single word icham. Its consequence was a mistaken analysis of such forms into $i$ and cham, with the former obtaining the status of an independent word. The lengthening of stressed $i / I$, which apparently had a compensatory character following the loss of final $<\mathrm{ch}>$, must have taken place in the latter half of the 15th century, thus creating a proper input to diphthongization by the Great Vowel Shift.

2. Orthography and function. Following the loss of the final velar non-capital $i$ was difficult to handle in writing, especially that it was a high frequency word, hence efforts to replace it by other letters, such as small $y, j$ and their capitalized variants, consequently rejected by the English language users. A replacement of the grapheme $<\mathrm{i}>$ by $<\mathrm{y}>$ had an old tradition if we recall the Middle English spelling kyng, instead of king, where the grapheme $<\mathrm{y}>$ replaced $<\mathrm{i}>$ for reasons of transparency.

3. Sociolinguistics. With the progress of literacy in England many people with standard education communicated with others writing letters. The collection of the 5 volumes containing The Paston Letters shows that capitalized I was used in private correspondence almost exclusively. In all probability capitalization of $<\mathrm{i}\rangle$ in epistolary literature must have reflected the high self-esteem of the letter writers who thought that capitalized $<$ I $>$ will add them prestige. 


\section{REFERENCES}

Brunner, Karl. 1962. Die englische Sprache. Band 2. Tübingen: Niemeyer.

Brunner, Karl. 1963. An outline of Middle English grammar. Translated by Grahame K. W. Johnston. Oxford: Blackwell.

Brunner, Karl. 1965. Altenglische Grammatik nach der angelsächsischen Grammatik von Eduard Sievers. (3rd edn.) Tübingen: Niemeyer.

Fisiak, Jacek. 1968. A short grammar of Middle English. Orthography, phonology and morphology. Warszawa: Państwowe Wydawnictwo Naukowe.

Hogg, Richard M. \& Robert D. Fulk. 2011. A grammar of Old English. Vol. 2: Morphology. Chichester: Wiley - Blackwell.

Horobin, Simon \& Jeremy Smith. 2002. An introduction to Middle English. Oxford: Oxford University Press.

Mallory, James P. \& Douglas Q. Adams. 2006. The Oxford introduction to Proto-Indo-European and the Proto-Indo-European world. Oxford: Oxford University Press.

Marcus, Manfred (ed.). 2008. Innsbruck corpus of Middle English prose. Innsbruck: Innsbruck Computer Archive of Machine-Readable English Texts.

Mossé, Fernand. 1952. A handbook of Middle English. Translated by James A. Walker. Baltimore: The John Hopkins University Press.

Ringe, Don. 2006. From Proto-Indo-European to Proto-Germanic. Oxford: Oxford University Press.

Wright, Joseph \& Elizabeth Mary Wright. 1928. An elementary Middle English grammar. (2nd ed.) London: Oxford University Press. 